\title{
Penilaian Status Kesuburan Tanah Desa Tijayan Kecamatan Manisrenggo Kabupaten Klaten
}

\section{Status of Soil Fertility Assessment in Tijayan Village, Manisrenggo District, Klaten}

\author{
Elvina Septianta Molle ${ }^{1^{*}}$, Andre Wijaya Setiawan $^{2}$, Alfred Jansen Sutrisno ${ }^{3}$ \\ ${ }^{1-3}$ Agrotechnology Study Program, Faculty of Agriculture and Business, Universitas Kristen Satya Wacana, Salatiga, Jawa \\ Tengah, 50711, Indonesia
}

Received 02 May 2021; Accepted 13 August 2021; Published 31 December 2021

\begin{abstract}
Tijayan Village is located in Manisrenggo District, Klaten Regency, which has an area of agricultural land in the form of rice fields which is 105.80 ha of 155.3 ha of the village area. The extent of agricultural land in Tijayan Village needs to be maintained to increase agricultural products ranging from rice, secondary crops, and horticulture commodities. The researcher found a lack of information about soil maintenance in Tijayan Village. Therefore, the researcher conducted this research to determine and study the soil fertility and soil management efforts based on the limiting factors of fertility in Tijayan Village. In addition, soil fertility assessment is based on a desk study, detailed survey, soil analysis, making fertility distribution maps, and descriptive analysis. Determination of soil fertility status based on Soil Research Guidelines published by Soil Research Center, Bogor Indonesia, with parameters of cation exchange capacity, base saturation, total phosphorus, total potassium, and C- organic. Map made by using the ArcGIS 10.4 application. The fertility of Tijayan Village is categorized as low soil fertility class. The limiting factors for soil fertility are soil cation exchange capacity $3.47 \mathrm{me} / 100 \mathrm{~g}$ until $12.33 \mathrm{me} / 100 \mathrm{~g}$, total potassium $<10 \mathrm{mg} / 100 \mathrm{~g}$, and C- organic $1.213 \%-2.286 \%$. Consequently, management needs to be done by adding organic matter to the soil, fertilizing organically or inorganically, and the principle of healthy plant cultivation for rice fields.
\end{abstract}

Keywords: organic matter; rice field; soil management, soil fertility

Cite this as (CSE Style): Yama DI, Ivansyah O, Astriy R. 2021. Hubungan serapan P dengan pertumbuhan setek lada pada aplikasi kompos ampas tahu dan jerami padi. Agrotechnology Res J. 5(2):48-54. https://dx.doi.org/10.20961/agrotechresj.v5i2.54230.

\section{PENDAHULUAN}

Indonesia merupakan negara agraris yang memiliki beragam hasil pertanian yang berguna untuk memenuhi kebutuhan pangan masyarakatnya. Tanaman padi merupakan tanaman penghasil beras yang merupakan makanan pokok utama di Indonesia. Produktivitas padi di Indonesia mengalami penurunan pada tahun 2019 yaitu 51,14 ku.ha-1 dari 52,03 ku.ha-1 (BPS 2019).

Produksi padi sangat bergantung pada kualitas kesuburan tanah serta penambahan pupuk dari luar, pupuk organik maupun pupuk anorganik. Penggenangan tanah dalam kegiatan budidaya padi dapat mengakibatkan kesuburan tanah menurun, penggenangan lahan dapat menghancurkan agregasi tanah dan turunnya kadar bahan organik pada tanah yang menyebabkan menurunnya kualitas tanah. Bahan

${ }^{*}$ Corresponding Author:

E-Mail: fpb.andre@uksw.edu organik dan agregat tanah yang baik merupakan hal yang mempengaruhi kesuburan tanah (Mohanty et al. 2007).

Produksi padi di Kabupaten Klaten pada tahun 2016 yaitu sebesar 406.270 ton (BPS 2018) Kecamatan Manisrenggo memasok 17.216 ton dari total produksi padi Kabupaten Klaten. Desa Tijayan terletak di Kecamatan Manisrenggo, Kabupaten Klaten, memiliki luas 155,3 ha yang didominasi oleh lahan pertanian sawah maupun non sawah. Lahan pertanian Desa Tijayan memproduksi hasil pertanian dengan musim tanaman mayoritas 3 (tiga) kali tanam dalam setahun dan komoditas yang ditanam yaitu padi, palawija, dan hortikultura.

Tanah di Desa Tijayan berupa tanah regosol coklat keabu-abuan yang memiliki kandungan abu vulkanik dari Gunung Merapi (Pemerintah Kabupaten Klaten 2011).Tekstur tanah didominasi oleh pasir dan kesuburan tanah yang rendah. Sutanto (2006), menegaskan bahwa kemampuan tanah sebagai tempat hidup tanaman yang menghasilkan bahan dapat dipanen sangat dipengaruhi oleh tingkat kesuburan sebagai 
alternatif kapasitas berproduksi. Kesuburan tanah juga merupakan kemampuan tanah untuk menyediakan hara dalam jumlah yang cukup untuk pertumbuhan dan perkembangan tanaman agar menghasilkan panen dengan kuantitas dan kualitas yang baik (Dharmayanti et al. 2013).

Tingkat kesuburan yang tinggi sangat dibutuhkan oleh Desa Tijayan untuk meningkatkan produksi guna memperkuat ketahanan pangan Kecamatan Manisrenggo hingga Kabupaten Klaten (Singh et al. 2012), menyatakan bahwa penggunaan lahan guna pengembangan tanaman budidaya umumnya didasarkan pada sifat tanaman dan karakteristik lahan seperti tanah, fisiografi, air permukaan, air tanah dalam, vegetasi alami, dan penggunaan lahan yang ada, serta kondisi sosial-ekonomi, tanpa mengganggu keseimbangan ekologi. Oleh karena itu tanah di Desa Tijayan memerlukan kondisi kesuburan tanah yang baik untuk mendukung peningkatan hasil panen.

Penilaian status kesuburan tanah dapat dilakukan dengan metode pengujian tanah yang merupakan metode relatif lebih akurat dan cepat. Pengujian sifatsifat kimia tanah sebagai parameter kesuburan tanah kemudian ditetapkan dalam kriteria kesuburan tanah (Pusat Penelitian Tanah 1995). Penetapan berdasarkan pengujian tanah ditujukan guna menilai karakteristik tanah hingga menentukan kendala utama kesuburan tanah (Siswanto 2006).

Penelitian ini dilakukan karena luas Desa Tijayan didominasi oleh lahan pertanian dan kurangnya informasi terkait kesuburan dan pengelolaan tanah untuk menjaga kesuburan tanah Desa Tijayan. Tujuan penelitian ini adalah mengkaji kondisi kesuburan tanah dari fisika tanah dan kimia tanah di Desa Tijayan sehingga didapatkan tingkat kesuburan dan faktor pembatas kesuburan tanah sebagai dasar pengelolaan tanah di Desa Tijayan Hal ini dilakukan agar dapat terjaganya kesuburan tanah di wilayah tersebut.

\section{BAHAN DAN METODE \\ Lokasi penelitian}

Penelitian dilakukan di Desa Tijayan, Kecamatan Manisrenggo, Kabupaten Klaten, Provinsi Jawa Tengah pada 1 Oktober 2021 hingga 30 Oktober 2021. Analisis tanah dilakukan di Laboratorium Tanah Fakultas Pertanian dan Bisnis, Universitas Kristen Satya Wacana Salatiga dan menggunakan jasa pengujian Laboratorium Kimia Badan Penelitian dan Pengembangan Pertanian oleh Balai Pengkajian Teknologi Pertanian Jawa Tengah.

\section{Bahan dan alat}

Bahan yang digunakan adalah peta administrasi desa, peta jenis tanah, peta kelerengan, peta penggunaan lahan dan sampel tanah tiap titik. Alat yang digunakan yaitu seperangkat alat pengambilan sampel tanah, Global Positioning System (GPS), seperangkat alat analisis tanah $\left(\mathrm{P}_{2} \mathrm{O}_{5}\right.$ Total, $\mathrm{K}_{2} \mathrm{O}$ Total, C- organik, $\mathrm{pH}$ dan tekstur), dan software ArcGIS 10.4 sebagian tools pembuat peta.

\section{Pengumpulan data penelitian}

Pengambilan sampel tanah untuk diuji akan menghasilkan data primer dengan analisis laboratorium dan data sekunder diperoleh dari Pemerintah Desa dan beberapa dinas di Kabupaten Klaten.

\section{Prosedur penelitian}

Penelitian dilakukan dengan desk study, survei lapangan tingkat detail guna menentukan titik sampel dengan purposive sampling. Titik sampel yang diambil yaitu sebanyak 15 titik yang mewakili satu Desa Tijayan (Tabel 1). Pengambilan sampel tanah dilakukan pada kedalaman tanah 0-20 cm.

Tabel 1. Titik koordinat tiap sampel dan vegetasi di Desa Tijayan.

\begin{tabular}{|c|c|c|c|}
\hline \multirow{2}{*}{ No } & \multicolumn{2}{|c|}{ Titik Koordinat } & \multirow{2}{*}{ Vegetasi } \\
\hline & $\mathrm{x}$ & $y$ & \\
\hline 1 & $7^{\circ} 40^{\prime} 56.64 " \mathrm{~S}$ & $110^{\circ} 29^{\prime} 49.44^{\prime \prime} \mathrm{E}$ & Kacang \\
\hline 2 & $7^{\circ} 41^{\prime} 5.76$ "S & $110^{\circ} 29^{\prime} 47.22^{\prime \prime} \mathrm{E}$ & Jagung \\
\hline 3 & $7^{\circ} 41^{\prime} 0.36^{\prime \prime} S$ & $110^{\circ} 29^{\prime} 58.08^{\prime \prime} \mathrm{E}$ & Cabai \\
\hline 4 & 7०41'12.72"S & $110^{\circ} 29^{\prime} 55.80^{\prime \prime} \mathrm{E}$ & Cabai \\
\hline 5 & 7041'23.76"S & $110^{\circ} 29^{\prime} 5.70 " \mathrm{E}$ & Kacang \\
\hline 6 & 7041'28.86"S & $110^{\circ} 29^{\prime} 55.92$ 'E & Tembakau \\
\hline 7 & 7041'14.28"S & $110^{\circ} 30^{\prime} 22.80^{\prime \prime} \mathrm{E}$ & Tembakau \\
\hline 8 & $7^{\circ} 41^{\prime} 27.84 " S$ & $110^{\circ} 30^{\prime} 18.90^{\prime \prime} \mathrm{E}$ & Cabai \\
\hline 9 & $7^{\circ} 41^{\prime} 34.56$ "S & $110^{\circ} 30^{\prime} 2.58^{\prime \prime} \mathrm{E}$ & Tembakau \\
\hline 10 & 7041'47.38"S & $110^{\circ} 30^{\prime} 2.71^{\prime \prime E}$ & Cabai \\
\hline 11 & 7041'41.34"S & $110^{\circ} 30^{\prime} 9.06^{\prime \prime} \mathrm{E}$ & Oyong \\
\hline 12 & 7041'35.52"S & $110^{\circ} 30^{\prime} 20.58^{\prime \prime} \mathrm{E}$ & Tembakau \\
\hline 13 & 7041'44.40"S & $110^{\circ} 30^{\prime} 22.26^{\prime \prime} \mathrm{E}$ & Kacang \\
\hline 14 & 7041'14.16"S & $110^{\circ} 29^{\prime} 45.18^{\prime \prime} \mathrm{E}$ & Tembakau \\
\hline 15 & 7041'19.56"S & 110³0'15.06"E & Kacang \\
\hline
\end{tabular}

Sampel tanah diuji di Laboratorium Tanah Fakultas Pertanian dan Bisnis, uji yang dilakukan yaitu uji fisika berupa tekstur tanah dan kimia tanah berupa $\mathrm{P}_{2} \mathrm{O}_{5}$ total (Metode $\mathrm{HCl} 25 \%$ dengan Spektrofotometri panjang gelombang ), $\mathrm{K}_{2} \mathrm{O}$ total (Metode $\mathrm{HCl} 25 \%$ ), , C-organik (Metode Spektrofotometri dengan panjang gelombang $584 \mathrm{~nm}$ ), dan $\mathrm{pH}$ (Metode $\mathrm{H}_{2} \mathrm{O}$ dengan $\mathrm{pH}$ meter). Pengujian KTK (Metode Titrimetri) dan KB (Metode Spektrofotometri) dilakukan oleh Laboratorium Kimia Badan Penelitian dan Pengembangan Pertanian oleh Balai Pengkajian Teknologi Pertanian Jawa Tengah. Data hasil pengujian tanah di input ke dalam peta administrasi desa dan dilakukan interpolasi data dan pengkelasan kriteria harkat tanah berdasarkan Pusat Penelitian Tanah (1995) seperti disajikan pada Tabel 2 dan Tabel 3. Selanjutnya dilakukan analisis Sistem Informasi Geografis dengan aplikasi Arc.Gis 10.4, analisis yang dilakukan dengan interpolasi Inverse Distance Weighting (IDW) dan overlay sebaran peta kesuburan tanah Desa Tijayan dengan peta administrasi Desa Tijayan. Analisis deskriptif dilakukan berdasarkan hasil kelas kesuburan tanah, penentuan faktor pembatas, dan pemberian rekomendasi pengelolaan kesuburan tanah. 
Tabel 2. Indeks status kesuburan tanah berdasarkan Pusat Penelitian Tanah (1995)

\begin{tabular}{cccc}
\hline & KTK & $\mathrm{P}_{2} \mathrm{O}_{5}$, & \\
No & dan & $\mathrm{K}_{2} \mathrm{O}$, & Status Kesuburan \\
& $\mathrm{KB}$ & C-organik & \\
\hline
\end{tabular}

\begin{tabular}{ccccc}
\hline 1. & $\mathrm{T}$ & $\mathrm{T}$ & $\geq 2 \mathrm{~T}$ tanpa R & Tinggi \\
2. & $\mathrm{T}$ & $\mathrm{T}$ & $\geq 2 \mathrm{~T}$ dengan R & Sedang \\
3. & $\mathrm{T}$ & $\mathrm{T}$ & $\geq 2 \mathrm{~S}$ tanpa R & Tinggi \\
4. & $\mathrm{T}$ & $\mathrm{T}$ & $\geq 2 \mathrm{~S}$ dengan R & Sedang \\
5. & $\mathrm{T}$ & $\mathrm{T}$ & $\mathrm{T}>\mathrm{S}>\mathrm{R}$ & Sedang \\
6. & $\mathrm{T}$ & $\mathrm{T}$ & $\geq 2 \mathrm{R}$ dengan $\mathrm{T}$ & Sedang \\
7. & $\mathrm{T}$ & $\mathrm{T}$ & $\geq 2 \mathrm{R}$ dengan S & Rendah \\
\hline 8. & $\mathrm{T}$ & $\mathrm{S}$ & $\geq 2 \mathrm{~T}$ tanpa $\mathrm{R}$ & Tinggi \\
9. & $\mathrm{T}$ & $\mathrm{S}$ & $\geq 2 \mathrm{~T}$ dengan $\mathrm{R}$ & Sedang \\
10. & $\mathrm{T}$ & $\mathrm{S}$ & $\geq 2 \mathrm{~S}$ & Sedang
\end{tabular}

\begin{tabular}{ccccc} 
11. & $\mathrm{T}$ & $\mathrm{S}$ & Kombinasi lain & Rendah \\
\hline 12. & $\mathrm{T}$ & $\mathrm{R}$ & $\geq 2 \mathrm{~T}$ tanpa $\mathrm{R}$ & Sedang \\
13. & $\mathrm{T}$ & $\mathrm{R}$ & $\geq 2 \mathrm{~T}$ dengan $\mathrm{R}$ & Rendah
\end{tabular}

\begin{tabular}{ccccc} 
14. & $\mathrm{T}$ & $\mathrm{R}$ & Kombinasi lain & Rendah \\
\hline 15. & $\mathrm{S}$ & $\mathrm{T}$ & $\geq 2 \mathrm{~T}$ tanpa $\mathrm{R}$ & Sedang
\end{tabular}

16. $S \quad T \quad \geq 2 S$ tanpa $R$ Sedang

\begin{tabular}{ccccc} 
17. & $S$ & $T$ & Kombinasi lain & Rendah \\
\hline 18. & $S$ & $S$ & $\geq 2 \mathrm{~T}$ tanpa $R$ & Sedang
\end{tabular}

19. S $S \quad \geq 2 \mathrm{~S}$ tanpa R Sedang

\begin{tabular}{ccccc} 
20. & S & S & Kombinasi Lain & Rendah \\
\hline 21. & $S$ & $R$ & $3 T$ & Sedang
\end{tabular}

\begin{tabular}{ccccc} 
22. & $\mathrm{S}$ & $\mathrm{R}$ & Kombinasi Lain & Rendah \\
\hline 23. & $\mathrm{R}$ & $\mathrm{T}$ & $\geq 2 \mathrm{~T}$ tanpa $\mathrm{R}$ & Sedang
\end{tabular}

24. $R \quad T \quad \geq 2 T$ dengan $R$ Rendah

25. $R \quad T \quad \geq 2 S$ tanpa $R$ Sedang

\begin{tabular}{ccccc} 
26. & $\mathrm{R}$ & $\mathrm{T}$ & Kombinasi lain & Rendah \\
\hline 27. & $\mathrm{R}$ & $\mathrm{S}$ & $\geq 2 \mathrm{~T}$ tanpa $\mathrm{R}$ & Sedang
\end{tabular}

28. $\mathrm{R}$ S kombinasi lain Rendah

\begin{tabular}{ccccc}
\hline 29. & $\mathrm{R}$ & $\mathrm{R}$ & $\begin{array}{c}\text { Semua } \\
\text { kombinasi }\end{array}$ & Rendah \\
\hline 30. & SR & T, S, R & $\begin{array}{c}\text { Semua } \\
\text { kombinasi }\end{array}$ & $\begin{array}{c}\text { Sangat } \\
\text { Rendah }\end{array}$ \\
\hline
\end{tabular}

Keterangan: Harkat "ST" adalah Sangat Tinggi; Harkat "T" adalah Tinggi; Harkat "S" adalah Sedang; Harkat "R" adalah Rendah; Harkat "SR" adalah Sangat Rendah"
Tabel 3. Kriteria penilaian kelas harkat tanah sifat kimia tanah berdasarkan Pusat Penelitian Tanah (1995)

\begin{tabular}{|c|c|c|c|}
\hline No & Sifat Kimia & Nilai & $\begin{array}{c}\text { Klas Harkat } \\
\text { Tanah }\end{array}$ \\
\hline \multirow[t]{5}{*}{1} & KTK (me/100 g) & $>40$ & ST \\
\hline & & $25-40$ & $\mathrm{~T}$ \\
\hline & & $17-24$ & $\mathrm{~S}$ \\
\hline & & $5-16$ & $\mathrm{R}$ \\
\hline & & $<5$ & SR \\
\hline \multirow[t]{5}{*}{2} & Kejenuhan Basa (\%) & $>70$ & ST \\
\hline & & $51-70$ & $\mathrm{~T}$ \\
\hline & & $36-50$ & S \\
\hline & & $20-35$ & $\mathrm{R}$ \\
\hline & & $<20$ & SR \\
\hline \multirow[t]{5}{*}{3} & C-organik (\%) & $>5,00$ & ST \\
\hline & & $3,01-5,00$ & $\mathrm{~T}$ \\
\hline & & $2,01-3,00$ & $S$ \\
\hline & & $1,00-2,00$ & $\mathrm{R}$ \\
\hline & & $<1,00$ & SR \\
\hline \multirow[t]{5}{*}{$\overline{4}$} & $\mathrm{P}_{2} \mathrm{O}_{5}(\mathrm{mg} / 100 \mathrm{~g})$ & $>60$ & ST \\
\hline & & $41-60$ & $\mathrm{~T}$ \\
\hline & & $21-40$ & S \\
\hline & & $10-20$ & $\mathrm{R}$ \\
\hline & & $<10$ & SR \\
\hline \multirow[t]{5}{*}{5} & $\mathrm{~K}_{2} \mathrm{O}(\mathrm{mg} / 100 \mathrm{~g})$ & $>60$ & ST \\
\hline & & $41-60$ & $\mathrm{~T}$ \\
\hline & & $21-40$ & $\mathrm{~S}$ \\
\hline & & $10-20$ & $\mathrm{R}$ \\
\hline & & $<10$ & SR \\
\hline
\end{tabular}

Keterangan: Harkat "ST" adalah Sangat Tinggi; Harkat "T" adalah Tinggi; Harkat "S" adalah Sedang; Harkat "R" adalah Rendah; Harkat "SR" adalah Sangat Rendah"

\section{HASIL DAN PEMBAHASAN \\ Sifat fisika dan kimia tanah}

Tekstur tanah. Hasil pengujian menunjukkan bahwa Desa Tijayan memiliki 3 klasifikasi tekstur tanah yaitu: lempung, lempung berpasir dan lempung liat berpasir (Tabel 4). Hasil tekstur tanah Desa Tijayan sesuai dengan jenis tanah Regosol yaitu memiliki fraksi pasir yang tinggi dibandingkan dua fraksi tanah yang lainnya (Tabel 4). Menurut Holilullah et al. (2015) dan Haridjaja et al. (2013) tanah yang memiliki fraksi pasir lebih tinggi akan lebih mudah meloloskan air, dan teori ini ditunjukkan dengan hasil permeabilitas tanah Desa Tijayan yaitu $5,30-156,23 \mathrm{~cm} /$ jam. Kecilnya nilai fraksi liat akan mempengaruhi kadar hara dalam tanah. Hal ini sesuai dengan penelitian Riniarti dan Setiawan (2014), yang menyatakan tanah dengan fraksi liat yang tinggi dapat mengikat dan mempertahankan nutrisi, sehingga dapat diserap oleh akar guna pertumbuhan tanaman.

pH dan C-Organik. Hasil pengujian menunjukkan (Tabel 4) memiliki 3 (tiga) kriteria kemasaman tanah yaitu asam, agak masam, dan netral. Menurut Hadun dan Teapon (2020), kondisi pH tanah yang masam dapat mempengaruhi terbatasnya hara yang tersedia bagi tanaman terutama hara fosfor. Bahan organik pada tanah mempengaruhi sifat fisik, kimia, dan biologi tanah. Bahan organik yang digunakan untuk menilai kesuburan tanah yaitu C-organik. 
Tabel 4. Hasil pengujian sifat fisika dan kimia tanah dan status kesuburan tanah di Desa Tijayan

\begin{tabular}{|c|c|c|c|c|c|c|c|c|}
\hline No & Tekstur & $\mathrm{pH}$ & KTK & KB & $\mathrm{P}_{2} 05$ Total & $\mathrm{K}_{2} \mathrm{O}$ Total & C- organik & $\begin{array}{l}\text { Status } \\
\text { Kesuburan }\end{array}$ \\
\hline 1 & $\begin{array}{l}\text { Lempung } \\
\text { liat berpasir }\end{array}$ & Netral & $\mathrm{R}$ & ST & ST & SR & $\mathrm{R}$ & $\mathrm{R}$ \\
\hline 2 & Lempung & $\begin{array}{l}\text { Agak } \\
\text { Masam }\end{array}$ & $\mathrm{R}$ & ST & ST & SR & $S$ & $\mathrm{R}$ \\
\hline 3 & $\begin{array}{l}\text { Lempung } \\
\text { berpasir }\end{array}$ & $\begin{array}{l}\text { Agak } \\
\text { Masam }\end{array}$ & SR & ST & ST & SR & $\mathrm{R}$ & SR \\
\hline 4 & $\begin{array}{l}\text { Lempung } \\
\text { liat berpasir }\end{array}$ & $\begin{array}{l}\text { Agak } \\
\text { Masam }\end{array}$ & $\mathrm{R}$ & ST & ST & $\mathrm{SR}$ & $\mathrm{R}$ & $\mathrm{R}$ \\
\hline 5 & $\begin{array}{l}\text { Lempung } \\
\text { berpasir }\end{array}$ & $\begin{array}{l}\text { Agak } \\
\text { Masam }\end{array}$ & $\mathrm{R}$ & ST & ST & SR & $R$ & $\mathrm{R}$ \\
\hline 6 & $\begin{array}{l}\text { Lempung } \\
\text { berpasir }\end{array}$ & $\begin{array}{l}\text { Agak } \\
\text { Masam }\end{array}$ & $\mathrm{R}$ & ST & ST & SR & $S$ & $\mathrm{R}$ \\
\hline 7 & $\begin{array}{l}\text { Lempung } \\
\text { berpasir }\end{array}$ & Asam & $\mathrm{R}$ & ST & ST & SR & $R$ & SR \\
\hline 8 & $\begin{array}{l}\text { Lempung } \\
\text { berpasir }\end{array}$ & $\begin{array}{l}\text { Agak } \\
\text { Masam }\end{array}$ & $\mathrm{R}$ & ST & ST & $\mathrm{SR}$ & $\mathrm{R}$ & $\mathrm{R}$ \\
\hline 9 & $\begin{array}{l}\text { Lempung } \\
\text { liat berpasir }\end{array}$ & $\begin{array}{l}\text { Agak } \\
\text { Masam }\end{array}$ & $\mathrm{R}$ & ST & ST & SR & $S$ & $\mathrm{R}$ \\
\hline 10 & $\begin{array}{l}\text { Lempung } \\
\text { liat berpasir }\end{array}$ & $\begin{array}{l}\text { Agak } \\
\text { Masam }\end{array}$ & $\mathrm{R}$ & ST & ST & SR & $S$ & $\mathrm{R}$ \\
\hline 11 & $\begin{array}{l}\text { Lempung } \\
\text { berpasir }\end{array}$ & $\begin{array}{l}\text { Agak } \\
\text { Masam }\end{array}$ & $\mathrm{R}$ & ST & ST & SR & $\mathrm{R}$ & $\mathrm{R}$ \\
\hline 12 & $\begin{array}{l}\text { Lempung } \\
\text { berpasir }\end{array}$ & $\begin{array}{l}\text { Agak } \\
\text { Masam }\end{array}$ & $\mathrm{R}$ & ST & ST & SR & $\mathrm{R}$ & $\mathrm{R}$ \\
\hline 13 & $\begin{array}{l}\text { Lempung } \\
\text { berpasir }\end{array}$ & Netral & $\mathrm{R}$ & ST & ST & SR & $\mathrm{R}$ & $\mathrm{R}$ \\
\hline 14 & $\begin{array}{l}\text { Lempung } \\
\text { liat berpasir }\end{array}$ & Netral & $\mathrm{R}$ & ST & ST & $\mathrm{SR}$ & $\mathrm{R}$ & $\mathrm{R}$ \\
\hline 15 & $\begin{array}{l}\text { Lempung } \\
\text { berliat }\end{array}$ & $\begin{array}{l}\text { Agak } \\
\text { Masam }\end{array}$ & $\mathrm{R}$ & ST & ST & SR & $\mathrm{R}$ & $\mathrm{R}$ \\
\hline
\end{tabular}

Keterangan: Harkat "ST" adalah Sangat Tinggi; Harkat "T" adalah Tinggi; Harkat "S" adalah Sedang; Harkat "R" adalah Rendah; Harkat "SR" adalah Sangat Rendah"

Hasil pengujian (Tabel 4) menunjukkan bahwa Corganik di Desa Tijayan termasuk dalam taraf sedang hingga rendah. Ketersediaan bahan organik menurut Xia et al. (2021), dipengaruhi oleh tekstur tanah. Tekstur tanah yang berpasir dan kondisi drainase yang dapat dilihat dari hasil permeabilitas sangat menunjukkan mengapa C-organik di Desa Tijayan termasuk rendah. Kegiatan budidaya tanaman yang tidak mengembalikan sisa hasil panen berupa jerami dalam penanaman padi sawah juga menyebabkan rendahnya C-organik. BBPADI (2019) menyatakan bahwa pengembalian sisa jerami dapat meningkatkan bahan organik dan mampu meningkatkan kapasitas ketersediaan air. Penelitian oleh Minasny dan McBratney (2018) menyatakan sisa jerami dapat meningkatkan suplai hara, dan memperbaiki sifat fisik tanah. Ketersediaan bahan organik juga dipengaruhi oleh kemasaman tanah.

\section{Kapasitas tukar kation dan kejenuhan basa}

Kapasitas tukar kation menunjukkan kemampuan tanah dalam menukarkan sejumlah kation. Kemampuan tukar kation ini dipengaruhi oleh $\mathrm{pH}$ tanah, kandungan bahan organik, dan kandungan liat Kapasitas tukar kation tanah Desa Tijayan termasuk rendah hingga sangat rendah yaitu $3,47 \mathrm{me} / 100 \mathrm{~g}$ hingga $12,33 \mathrm{me} / 100$ g (Tabel 4). Menurut Darlita et al. (2017), semakin tinggi kandungan liat dan bahan organik, maka kapasitas tukar kation pada tanah akan meningkat juga. Teori ini menunjukkan korelasi rendahnya kapasitas tukar kation dengan rendahnya $\mathrm{pH}$ dan bahan organik.

Hasil pengujian menyatakan bahwa kejenuhan basa di Desa Tijayan termasuk sangat tinggi (Tabel 4). Menurut Husni et al. (2016), tanah subur memiliki kejenuhan basa $>80 \%$. Tingginya kejenuhan basa Desa Tijayan yang nilainya $>80 \%$ belum bisa dikatakan subur, karena harus dipertimbangkan dengan sifat kimia dan fisika lainnya yang mempengaruhi kesuburan tanah. Menurut Suarjana et al. (2016), nilai KB tanah dengan $\mathrm{pH}$ tanah memiliki hubungan yang bersifat positif dimana $\mathrm{pH}$ tanah tinggi akan diikuti dengan nilai KB yang tinggi. Teori tersebut berbanding terbalik dari hasil pengujian, dimana $\mathrm{pH}$ tanah di Desa Tijayan asam dan nilai KB yang tinggi.

Kejenuhan basa berhubungan dengan faktor pembentuk tanah dan ketinggian tempat (Sari et al. 2013). Pinatih et al. (2016) menyatakan bahwa tingginya hasil pengujian kejenuhan basa dapat dikarenakan tanah lokasi masih tergolong muda yang masih berkembang dan topografi datar sehingga kecil terjadinya erosi. Tanah di Desa Tijayan merupakan tanah Regosol- Entisol yang dinyatakan oleh Department of United States Agriculture (USDA) (2014), merupakan tanah yang tergolong muda dan masih 
berkembang. Tanah di Desa Tijayan juga mengandung abu vulkanik Pemerintah Kabupaten Klaten (2011),dan Mulyaningsih et al. (2012), menyatakan bahwa adanya unsur-unsur makro seperti $\mathrm{Na}, \mathrm{Ca}, \mathrm{Mg}$ pada abu vulkanik. Hal ini bisa juga dikaitkan oleh tingginya kejenuhan basa di Desa Tijayan.

$\mathbf{P}_{2} \mathbf{O}_{5}$ total. Hasil pengujian menyatakan bahwa kandungan fosfor di Desa Tijayan termasuk sangat tinggi (Tabel 4). Kandungan hara P yang tinggi ini disebabkan oleh tanah di Desa Tijayan yang masih tergolong muda dan curah hujan yang cukup rendah juga yang mengakibatkan kandungan $\mathrm{P}$ pada tanah yang cukup tinggi sejalan dengan Tufaila and Alam (2014), bahwa tanah yang muda dan curah hujan yang rendah biasanya mengandung $P$ yang cukup tinggi.

$\mathrm{K}_{2} \mathrm{O}$ total. Hasil pengujian kalium total pada tanah Desa Tijayan yaitu sangat rendah karena hasilnya $<10$ mg/100g (Tabel 4). Menurut Handayanto et al. (2017), ketersediaan kalium pada tanah tergantung jenis dan jumlah mineral yang dikandung oleh tanah. Kalium pada tanah memiliki tiga jenis sebutan yaitu K-tidak tersedia, K-lambat tersedia, dan K-tersedia. Faktor yang mempengaruhi kandungan hara pada tanah yaitu kapasitas tukar kation, penyusun basa kation, dan tekstur tanah. Simatupang et al. (2021), menyatakan bahwa umumnya pada tanah yang nilai kapasitas tukar kationnya besar memiliki kalium yang besar juga, tanah Desa Tijayan memiliki nilai kapasitas tukar kation yang rendah maka menghasilkan nilai kalium yang rendah juga. Koloid tanah yang tinggi dapat mengurangi pencucian kalium yang mudah bergerak Soekamto (2015) koloid tanah rendah di Desa Tijayan ditunjukkan oleh rendahnya fraksi liat dan membuat kalium lebih mudah tercuci (Tabel 4).

\section{Penilaian kesuburan tanah dan faktor pembatas}

Penilaian status kesuburan tanah di Desa Tijayan tergolong rendah dan sangat rendah, tetapi secara umum kondisi tanah di Desa Tijayan dikategorikan dalam status kesuburan rendah berdasarkan dominasi kelas tersebut (Gambar 1). Setiap penilaian status kesuburan tanah pasti memiliki faktor pembatas kesuburan.

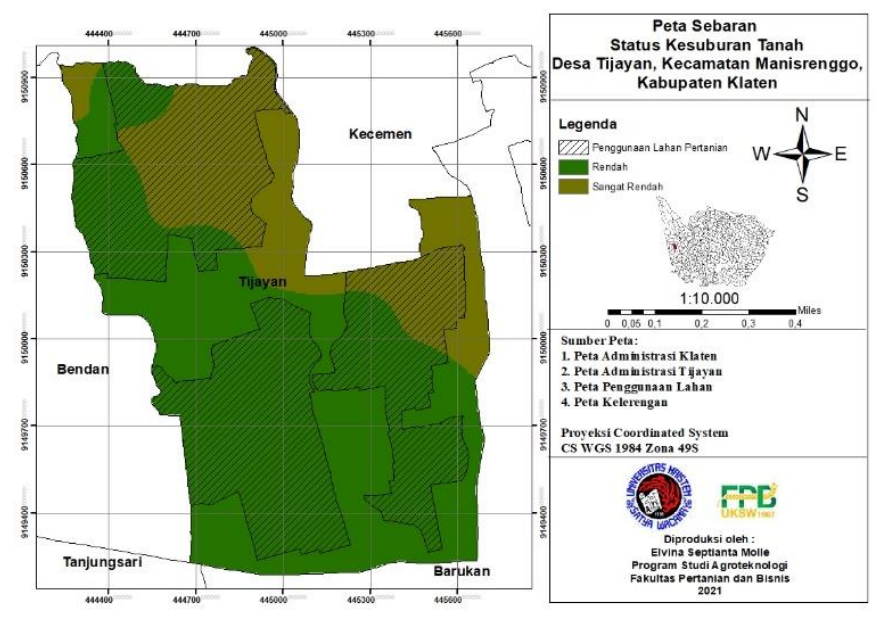

Gambar 1. Peta sebaran status kesuburan Desa Tijayan

\section{Hubungan status kesuburan tanah dengan sistem budidaya}

Kegiatan pertanian di Desa Tijayan mengikuti musim, pada musim hujan lahan mayoritas diubah menjadi lahan sawah, pada musim kering lahan digunakan sebagai lahan penanaman palawija dan hortikultura. Hal ini disebabkan petani sulit mendapatkan air untuk irigasi lahan sawah, sehingga pada pertanaman palawija dan hortikultura mayoritas petani menggunakan sistem "ngelep" yaitu mengairi parit bedengan dengan air dan air dibiarkan tergenang selama beberapa jam, lalu air dibuang, dan akan diairi satu hingga dua minggu lagi.

Frekuensi tanam petani di Desa Tijayan mayoritas 3 (tiga) kali musim tanam dalam 1 (satu) tahun, padipalawija/hortikultura- palawija/ hortikultura. Penanaman padi biasa dilakukan 2 (dua) kali satu tahun jika air memadai. Petani di Desa Tijayan pada penanaman padi sawah sering tidak meninggalkan sisa hasil panennya di sawah. Hal ini menunjukkan hasil yang sejalan dengan status kesuburan tanah yang rendah di Desa Tijayan.

Petani di Desa Tijayan memasang mulsa plastik untuk pertanaman palawija dan hortikultura. Pemasangan mulsa diawali dengan pembuatan bedengan yang dicampur dengan pupuk awal yaitu pupuk kandang. Pemupukan kandang yang digunakan lebih banyak karena penanaman dengan mulsa akan dilakukan 2 (dua) hingga 3 (tiga) kali musim tanam. Hal ini diterapkan petani untuk menghemat biaya produksi. Rendahnya penginputan bahan organik pada pertanaman palawija dan hortikultura sejalan dengan status kesuburan tanah yang rendah di Desa Tijayan.

\section{Faktor pembatas dan rekomendasi pengelolaannya}

Faktor pembatas kesuburan Desa Tijayan yaitu KTK, $\mathrm{K}_{2} \mathrm{O}$ total, dan $\mathrm{C}$-organik tanah. Hal ini disebabkan nilai harkat yang rendah hingga sangat rendah pada ketiga parameter.

Kapasitas tukar kation (KTK). Kandungan KTK yang rendah pada tanah disebabkan sedikitnya kandungan koloid yang ditunjukkan dari rendahnya fraksi tanah pada tekstur tanah Desa Tijayan. Hal yang sebaiknya dilakukan untuk meningkatkan kapasitas tukar kation adalah menambahkan bahan organik seperti pupuk kandang, pupuk kompos, atau pengembalian sisa hasil panen. Menurut Pakpahan et al. (2016), menyatakan pemberian pupuk kandang sapi menyumbang peningkatan KTK yang cukup tinggi dari koloid organik yang dihasilkan.

Kalium Tanah. Faktor pembatas kalium tanah disebabkan rendahnya kadar kalium di tanah Desa Tijayan. Kalium merupakan kation basa yang mudah tercuci sehingga hasil pengujian hanya ditemukan sedikit pada tanah. Hal yang dapat dilakukan untuk menambahkan kalium pada tanah, mengingat kalium merupakan salah satu dari ketiga hara yang esensial bagi pertumbuhan tanaman. Peningkatan kalium dapat dilakukan dengan menambahkan hara kalium secara organik maupun anorganik. Penambahan secara organik sangat di anjurkan karena selain menambah kalium juga memperbaiki sifat tanah lainnya, secara organik yaitu dengan pengembalian sisa hasil panen dan penambahan bioaktivator guna mempercepat dekomposisi sisa hasil panen, mengingat ketersediaan air yang diefektifkan penggunaannya oleh petani (Subandi 2013). 
C-organik. C-organik menjadi faktor pembatas kesuburan karena kandungan bahan organik yang rendah di Desa Tijayan. Tindakan yang perlu dilakukan dalam peningkatan bahan organik yaitu dengan menambahkan bahan organik seperti kompos, pupuk kandang, dan pupuk cair organik. Selain itu pengembalian sisa panen ke dalam tanah dan budidaya tanaman yang sehat tanpa bahan kimia dapat meningkatkan bahan organik pada tanah, khususnya tanah untuk produksi padi sawah. Putri et al. (2017), menyatakan bahwa biochar jerami padi, tandan kosong kelapa sawit, kulit durian dan kotoran sapi dapat meningkatkan $\mathrm{pH}$ tanah, C-organik, dan P-tersedia.

Prinsip budidaya tanaman sehat untuk penanaman padi yaitu, 1). perbaikan kesuburan tanah dengan menambahkan pupuk organik dan kapur dolomit pada kegiatan pengolahan tanah guna menetralkan tanah dengan $\mathrm{pH}$ asam dan menetralkan senyawa beracun yang bersifat organik maupun anorganik. 2). Pengolahan tanah yang tepat dengan pengembalian sisa hasil panen dan ditunggu hingga fermentasi selesai, membiarkan selama 7 (tujuh) hari setelah penambahan bahan organik dan kapur dolomit sebelum ditanami. 3). Penggunaan bibit varietas unggul dengan menanam padi yang tahan terhadap hama wereng batang coklat dan penanaman menggunakan sistem jajar legowo. 4). Penanaman refugia sebagai tempat berlindung sementara bagi musuh alami. 5). Pengendalian hama dan penyakit secara terpadu menggunakan tindakan preventif yaitu agensi hayati.

Penggunaan prinsip ini selain menambahkan bahan organik pada tanah juga dapat meningkatkan produksi padi (DKPP DIY 2020).

\section{KESIMPULAN}

1. Status kesuburan tanah Desa Tijayan, tergolong rendah. Peta sebaran status kesuburan tanah dibuat dengan interpolasi IDW berdasarkan skoring dari hasil analisis kimia tanah.

2. Faktor pembatas kesuburan tanah Desa Tijayan yaitu KTK (kapasitas tukar kation), $\mathrm{K}_{2} \mathrm{O}$ total, dan Corganik. Rekomendasi pengelolaan yaitu dengan penambahan bahan organik pemupukan organik atau anorganik, serta penggunaan prinsip budidaya tanaman sehat untuk pertanaman padi sawah.

\section{UCAPAN TERIMAKASIH}

Ucapan terima kasih ini saya sampaikan kepada Pemerintah Desa Tijayan yang sudah mengizinkan saya untuk melakukan penelitian dan mempermudah segala proses kegiatan selama penelitian.

\section{DAFTAR PUSTAKA}

[BPS] Badan Pusat Statistik. 2018. Klaten dalam angka 2018. Klaten (ID): Badan Pusat Statistik Kabupaten Klaten.

[BPS] Badan Pusat Statistik. 2019. Klaten dalam angka 2019. Klaten (ID): Badan Pusat Statistik Kabupaten Klaten.

[BBPADI] Balai Besar Penelitian Tanaman Padi. 2019. Jerami sebagai bahan organik. Subang (ID):Balai Besar Penelitian Tanaman Padi.
Darlita RR, Joy B, Sudirja R. 2017. Analisis beberapa sifat kimia tanah terhadap peningkatan produksi kelapa sawit pada tanah pasir di perkebunan kelapa sawit Selangkun. J Agrik. 28(1):15-20. https://doi.org/10.24198/agrikultura.v28i1.12294.

Dharmayanti NKS, Supadma AAN, Arthagama IDM. 2013. Pengaruh pemberian Biourine dan dosis pupuk anorganik $(\mathrm{N}, \mathrm{P}, \mathrm{K})$ terhadap beberapa sifat kimia tanah pegok dan hasil tanaman bayam (Amaranthus sp.). J Agroekoteknologi Trop. 2(3):165-174.

[DKPP DIY] Dinas Pertanian dan Ketahanan Pangan Daerah Istimewa Yogyakarta. 2020. Apa itu Budidaya Tanaman Sehat Pada Komoditas Padi. Yogyakarta (ID): Dinas Pertanian dan Ketahanan Pangan Daerah Istimewa Yogyakarta.

Hadun R, Teapon A. 2020. Pemetaan tingkat bahaya erosi berbasis raster di Sub DAS Tugurara Kecamatan Ternate Utara. Phys Soc Geogr Res J. 2(1):1-6.

Handayanto E, Muddarisna N, Fiqri A. 2017. Pengelolaan Kesuburan Tanah. Malang (ID): UB Press.

Haridjaja O, Baskoro DPT, Setianingsih M. 2013. Perbedaan nilai kadar air kapasitas lapang berdsarkan metode Alhricks, drainase bebas, dan pressure plate pada berbagai tekstur tanah dan hubungannya dengan pertumbuhan bunga matahari (Helianthus annuus L.). J IImu Tanah Lingkung. 15(2):52-59. https://doi.org/10.29244/jitl.15.2.52-59.

Holilullah, Afandi, Novpriansyah H. 2015. Karakteristik sifat fisik tanah pada lahan produksi rendah dan tinggi di PT Great Giant Pineapple. J Agrotek Trop. 3(2):278-282. https://dx.doi.org/10.23960/jat.v3i2.2014.

Husni MR, Sufardi S, Khalil M. 2016. Evaluasi status kesuburan pada beberapa jenis tanah di lahan kering Kabupaten Pidie Provinsi Aceh. J IIm Mhs Pertan. 1:147-154. htpps://doi.org/10.17969/jimfp.v1i1.950.

Minasny B, McBratney AB. 2018. Limited effect of organic matter on soil available water capacity. Eur J Soil Sci. 69(1):39-47. https://doi.org/10.1111/ejss.12475.

Mohanty M, Painuli D, Misra A, Ghosh P. 2007. Soil quality effects of tillage and residue under rice-wheat cropping on a Vertisol in India. Soil Tillage Res. 92(1-2):243-250. https://doi.org/10.1016/j.still.2006.03.005.

Mulyaningsih TR, Kuntoro I, Alfian. 2012. Distribusi unsur makro dan mikro dalam abu gunung merapi Yogyakarta. 6(1):12-22. https://doi.org/10.20886/jklh.2012.6.1.12-22.

Pakpahan RI, Sarifuddin S, Supriadi S. 2016. Pemberian bahan amandemen untuk perbaikan retensi hara tanaman jeruk manis (Citrus Sinensis L.) di Desa Talimbaru Kecamatan Barusjahe Kabupaten Karo. J Agroekoteknologi Univ Sumat Utara. 4(1):1681-1689. 
Pemerintah Kabupaten Klaten. 2011. Geografi dan Topografi Kabupaten Klaten. Klaten (ID): Pemerintah Kabupaten Klaten.

Pinatih I, Kusmiyarti T, Susila K. 2016. Evaluasi status kesuburan tanah pada lahan pertanian di Kecamatan Denpasar Selatan. E-J Agroekoteknologi Trop .4(4):282-292.

Pusat Penelitian Tanah. 1995. Kombinasi beberapa sifat kimia tanah dan status kesuburan. Bogor (ID): Pusat Penelitian Tanah.

Putri VI, Mukhlis, Hidayat B. 2017. Pemberian beberapa jenis Biochar untuk memperbaiki sifat kimia tanah Ultisol dan pertumbuhan tanaman jagung. J Agroekoteknologi FP USU. 5(4):824-828.

Riniarti M, Setiawan A. 2014. Status kesuburan tanah pada dua tutupan lahan di Kesatuan Pengelolaan Hutan Lindung (KPHL) Batutegi Lampung. J Sylva Lestari. 2(2):99. https://doi.org/10.23960/jsl2299-104.

Sari NP, Santoso TI, Mawardi S. 2013. Sebaran tingkat kesuburan tanah pada perkebunan rakyat kopi Arabika di dataran tinggi ljen-Raung menurut ketinggian tempat dan tanaman penaung. Pelita Perkeb. 29(2):93 0107.

Simatupang RN, Trigunasih NM, Arthagama IDM. 2021. Evaluasi status kesuburan tanah pada penggunaan lahan sawah di Subak Kecamatan Denpasar Utara Berbasis sistem informasi geografis (SIG). Nandur. 1(3):112-121.

Singh RK, Murty HR, Gupta SK, Dikshit AK. 2012. An overview of sustainability assessment methodologies. Ecol Indic. 15(1):281-299. https://doi.org/10.1016/j.ecolind.2011.01.007.

Siswanto. 2006. Evaluasi Sumberdaya Lahan. Surabaya (ID): UPN Press.

Soekamto MH. 2015. Kajian status kesuburan tanah di lahan kakao Kampung Klain Distrik Mayamuk Kabupaten Sorong. J Agroforestri. 10(3):201-208.

Soil Survey Staff. 2014. Keys to Soil Taxonomy. 12th ed. United States (US): United States Department of Agriculture: Natural Resources Conservation Service.

Suarjana I, Supadma A, Arthagama I. 2016. Kajian status kesuburan tanah sawah untuk menentukan anjuran pemupukan berimbang spesifik lokasi tanaman padi di Kecamatan Manggis. E-Jurnal Agroekoteknologi Trop. 4(4):314-323.

Subandi. 2013. Role and management of potassium nutrient for food production in indonesia. Agric Innov Dev. 6(1):1-10.

Tufaila M, Alam S. 2014. Karakteristik tanah dan evaluasi lahan untuk pengembangan tanaman padi sawah di Kecamatan Oheo Kabupaten Konawe Utara. 24:184-194.

Xia S, Song Z, Wang Y, Wang W, Fu X, Singh BP, Kuzyakov Y, Wang H. 2021. Soil organic matter turnover depending on land use change: Coupling $\mathrm{C} / \mathrm{N}$ ratios, $\mathrm{\delta 13C}$, and lignin biomarkers. L Degrad Dev. 32(4):1591-1605. 